\title{
KOMUNIKASI DAKWAH DALAM KESENIAN NASYID
}

\section{Fitri Yanti}

Institut Agama Islam Negeri Raden Intan Lampung

Email: saputrairawan25@yahoo.com

\section{Abstract:}

This paper deals with Islamic psalm (nasyid) which contain moral messages, past memories, stories of the prophets, and call for Islamic preaching and spirit to build nation and state. It serves a lot of functions. Nasyid can serve as a method of preaching that is entertaining and conveying messages to Muslim community. With nasyid, messages of preaching conveyed are not boring to the targets of preaching, but they feel attracted to it. Therefore, it can be effective to call them to perform the good and to prevent the evil.

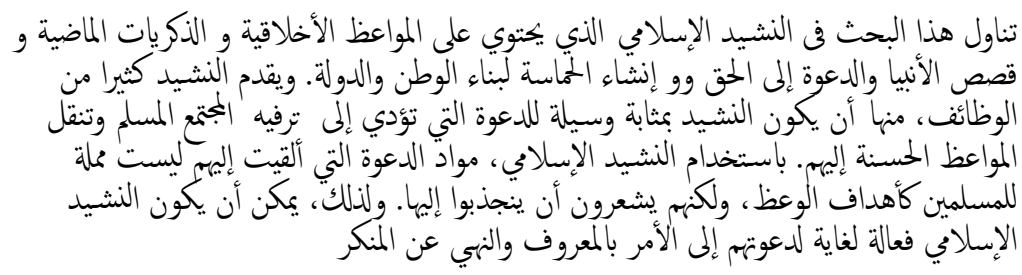

Kata Kunci: komunikasi dakwah, kesenian, nasyd

\section{Pendahuluan}

Berdakwah pada zaman sekarang ini tidak hanya melalui ceramah-ceramah di masjid pada umumnya tetapi juga berdakwah bisa dilakukan dengan beragam cara dan berdakwah juga bukan hanya pada satu tempat yaitu masjid tetapi juga berdakwah bisa dilakukan di banyak tempat. Pada zaman sekarang banyak media yang bisa digunakan untuk berdakwah seperti televisi, koran, majalah, buku, internet, bahkan lagu, sehingga pesan-pesan ajakan dakwah yang berupa nasihat, ajakan untuk 
kemaslahatan umat bisa tersampaikan dengan mudah. Fenomena perkembangan musik Islami ini terutama diwakili oleh album-album lagu Nasyid dengan kemasan baru sukses menarik perhatian generasi muda sekarang ini.

Keberhasilan dakwah dipengaruhi oleh metode, media yang digunakan, sebaik apapun penguasaan materi yang dimiliki oleh da'i bukan satu-satunya faktor penentu keberhasilan, kemampuan untuk memilih dan menggunakan metode dakwah yang tepat sesuai dengan kondisi obyektif mad'u akan meningkatkan kredit point. ${ }^{1}$ Bagi da'i. Ketepatan dalam memilih metode dan media dakwah akan sangat membantu da'i untuk lebih mudah menyampaikan psan-pesan dakwah.

Pada dasarnya agar pesan-pesan dakwah bisa tersampaikan dengan mudah pada masyarakat kita harus bisa menyesuaikan apa yang menjadi kebiasaan masyarakat dalam berperilaku, kebudayaan dan sebagainya. pendeknya, apa yang selalu menjadi kebiasaan mereka, disitulah kita bisa menjadikannya sebagai sarana untuk berdakwah.

Begitu pula dengan media dakwah melalui lagu yang saat ini banyak digemari para anak muda dan mudah sekali untuk dicerna pesan yang terkandung dalam syair lagu. Hal semacam ini kita bisa berdakwah di antaranya melalui pop religi dan nasyid. Melalui hal ini pesan-pesan Islam tanpa disadari akan sampai kepada mereka dengan mudah tanpa mengganggu kegemaran mereka sekaligus mengalihkan kegemaran dari hal-hal buruk kepada hal positif, yakni dari lagu-lagu bernuansa kekerasan, fantasi, dan roman teralihkan ke lagu-lagu yang bernuansa

${ }^{1}$ Fitri Yanti, Tabsyir dan Tanzir dalam Dakwah Perspektif Psikologi dalam Resolusi Konflik, Jurnal al-Ummah Vol. III No. 1 Januari 2008), h. 7 
religi karena tanpa disadari mereka akan merenungkan atau memikirkan pesan-pesan di dalam lagu-lagu yang mereka sukai.

Pada masa sekarang ini masyarakat semakin menggemari dan menyukai lagu-lagu yang bernuansa religi dari anak-anak, remaja, orang dewasa hingga orang tua maka disitulah kesempatan kita untuk menyampaikan ajakan-ajakan yang mengajak mereka untuk melakukan hal-hal yang sesuai dengan syari'at Islam. Apalagi pada zaman sekarang ini banyak perilaku-perilaku masyarakat yang menjauh dari nilai-nilai ajaran agama Islam. Dengan hal ini diharapkan bisa mengaplikasikannya di kehidupan sehari-hari agar perilaku-perilaku yang tadinya jauh dari nilai-nilai ajaran Islam.

Islam sendiri juga ternyata mengadopsi seni musik dalam mengambangkan agamanya. Awal perkembangan kesenian Islam mencapai puncak keemasaanya pada zaman Dinasti Ummayah hingga akhirnya menempatkan Baghdad sebagai pusat peradaban dunia. Dalam Islam pada masa itu, kesenian bukan hanya sebagai hiburan, tapi sudah menjadi ilmu pengetahuan yang terus diselidiki dan bagian dari ritual ibadah. Bahkan beberapa alat musik yang sekarang banyak digunakan di dunia berasal dari dunia kesenian Islam dan banyak karya dari seniman dunia Arab masa lalu yang menjadi acuan bagi seniman dunia barat dan belahan dunia lainnya. Di Nusantara, awal kedatangan Islam sempat mengemas baik ajaran Islam menggunakan seni musik oleh para walisanga. Mereka menggunakan seni music sebagai media dakwah menyebarkan Islam sebagai agama yang indah hingga orang-orang turut masuk di dalamnya.

Dalam perkembangannya nasyid semakin mendapat tempat di masyarakat. Ini ditandai dengan semakin bertambahnya tim nasyid dari 
tahun ke tahun dan perlu di catat yang gandrung terhadap nasyid datangnya dari generasi muda. Dari mulai kampus, sekolah, remaja mesjid sampai dengan pesantren tidak ada yang tidak mengenal nasyid.

Kesenian dalam Islam

Secara harfiah, seni merupakan bentuk dari karya manusia yang mengandung keindahan, mengandung pesona karya dan rasa jika diamati dan dinikmati. Kemudian memberikan kepuasan dan kesenangan pada setiap jiwa manusia dan seni adalah keindahan yang memberikan kepuasan dalam kehidupan kita sehari-hari. Maka seni dan kesenian adalah suatu jelmaan dari rasa keindahan yang wujud dari kerja manusia untuk mencapai kesejahteraan hidupnya. Disusun berdasarkan pemikiranpemikirannya sehingga ia menjadi suatu karya yang indah dan menimbulkan kesenangan untuk dinikmati.

Seni adalah penjelmaan rasa indah yang terkandung dalam jiwa manusia, yang dilahirkan dengan perantaraan alat komunikasi ke dalam bentuk yang dapat ditangkap oleh indera pendengar (seni suara), indera pendengar (seni lukis), atau dilahirkan dengan perantaraan gerak (seni tari, drama). Dilihat dari ruh ajaran Islam dan kaedahnya Islam tidak melarang sesuatu yang baik, indah dan kenikmatan yang diterima akal sehat. Sebagaimana dalam Surah Al-Maidah (5) ayat 4.

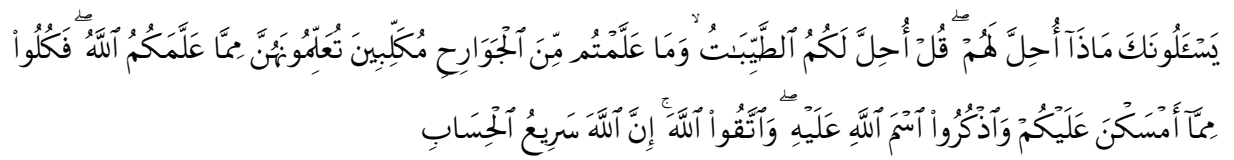

Terjemahnya:

"....Mereka bertanya kepadamu tentang apa yang dihalalkan Allah, katakanlah dihalalkan kepadamu segala yang baik-baik....".2 2010), h. 107

${ }^{2}$ Kementerian Agama RI, Alquran dan Terjemahnya, (Bandung: Fokusmedia, 


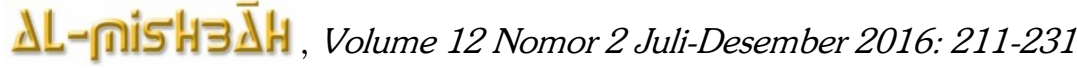

Seni merupakan fitrah yang Allah ciptakan dalam diri manusia. Sesungguhnya Islam adalah agama yang realistis, karena berinteraksi dengan manusia secara menyeluruh, jasmaninya, ruhaninya, akal dan perasaannya. Dalam Islam menuntut manusia agar ia memenuhi seluruh kebutuhannya selama dalam batas-batas yang seimbang. Apabila olahraga, berfungsi untuk menyegarkan tubuh, ibadah untuk menyegarkan rohani, ilmu untuk menyegarkan amal, maka seni berfungsi untuk menyegarkan perasaan. Jika jiwa seni adalah merasakan adanya keindahan dan menghayatinya, maka Alquran mengingatkan kita dengan tegas akan manfaat dan pentingnya unsur keindahan dan kecantikan yang telah Allah ciptakan pada setiap makhluk. ${ }^{3}$ Banyak sekali pengertian seni yang ditulis oleh para pakar dalam buku-bukunya sebagaimana fitroh manusia yang menyukai segala sesuatu yang indah dan menyenangkan, maka seni adalah usaha untuk menciptakan bentuk-bentuk yang menyenangkan. ${ }^{4}$ Seni juga merupakan manifestasi dari pada budaya. (Priksa, karsa, rasa, intuisi dan karya) manusia yang memenuhi syarat estetik. $^{5}$

Secara teoretis Islam memang tidak mengajarkan seni dan estetik (keindahan), namun tidaklah berarti Islam antiseni. Ungkapan bahwa Allah adalah jamil (keindahan) serta penyebutan allah pada diri-Nya

${ }^{3}$ Yusuf Qaradawi, (1997), h. 236.

${ }^{4}$ Sidi Ghazalba, Islam dan Kesenian; Relevansi Islam dengan seni Budaya Karya manusia, (Jakarta, Bulan Bintang, 1988), h, 81.

${ }^{5}$ Endang Saifuddin Anshari, Kuliah islam, (Jakarta: Rajawali Press, 1986), h 152. 
sebagai badi' ${ }^{6}$ as-samawat wa al-ardh, merupakan penegasan bahwa Islampun menghendaki kehidupan ini indah dan tidak lepas dari seni. ${ }^{7}$

Seni Islam merupakan hasil dari pengejewantahan keesaan dalam bidang keanekaragaman. Ia harus merefleksikan kandungan prinsip keesaan ilahi. Seni Islam harus mewujudkan, dalam taraf fisik yang secara langsung dapat dipahami oleh pikiran yang sehat, realitas-realitas dasar dan perbuatan-perbuatan sebagai tangga bagi pendakian jiwa dari tingkat yang dapat dilihat dan didengar menuju yang ghaib. ${ }^{8}$

Di dalam Islam musik yang khas, dengan latar belakang serta tujuan khusus yang berbeda dengan lagu populer adalah nyanyian religius. Nyanyian religius adalah nyanyian yang dihubungkan dengan nuansa keagamaan. Tujuan dan isi dari nyanyian tersebut adalah agama. Isi dan tujuan syair lagu tersebut menyeru dan mengingatkan kita pada jalan yang benar ${ }^{9}$ Karena syair lagu yang bernuansa keagamaan memiliki pengaruh keimanan yang kuat. ${ }^{10}$

Ada beberapa norma yang harus dipegang dalam berkesenian menurut Islam, yaitu:

1. Dilarang melukis lukisan yang bersifat pornografi, serta melukis hal-hal yang bernyawa.

2. Dilarang menciptakan hikayat yang menceritakan dewa-dewa, kebiasaan pengarang yang mengkritik Tuhan.

${ }^{6}$ Badi' adalah pencipta pertama dan brkonotasi indah. Berarti Allah mencipta langit dan bumi dengan keindahan. Lihat Sahal Mahfud, Nuansa Fiqh Sosial, (Yogyakarta, LKIS, 2003), h. 134

${ }^{7}$ Ibid.

${ }^{8}$ Syeed Hussen Nashr, (1994) h. 8

${ }^{9}$ Yusuf Qaradhawi, (2002), h. 161

${ }^{10}$ Ibid., h. 165 


\section{$\Delta L-\cap i s H \exists \bar{d} h$, Volume 12 Nomor 2 Juli-Desember 2016: 211-231}

3. Dilarang menyanyikan lagu-lagu yang berisikan kata-kata yang tidak sopan atau cabul.

4. Dilarang memainkan musik yang merangsang kepada gerakangerakan sensual.

5. Dilarang berpeluk-pelukan antara laki-laki dan perempuan atas nama tarian.

6. Dilarang menampilkan drama dan film yang melukiskan kekerasan, kebencian dan kekejaman.

7. Dilarang memakai pakaian yang memamerkan aurat. ${ }^{11}$

Kesenian Islam adalah kesinambungan daripada kesenian pada zaman silam yang telah berkembang dan dicorakkan oleh konsep tauhid yang tinggi kepada Allah swt. Kesenian Islam memiliki khazanah sejarahnya yang tersendiri dan unik. Kesenian Islam dikatakan telah berkembang sejak zaman Nabi Daud as. dan puteranya Nabi Sulaiman as. dan terus berkembang di zaman Nabi Muhammad saw dan di zaman selepas kewafatan rasul hingga kini. Kesenian Islam terus berkembang di dalam bentuk dan falsafahnya yang berorientasikan sumber Islam yang menitikberatkan kesejajaran dengan tuntutan tauhid dan syara'. Dalam jiwa, perasaan, nurani, dan keinginan manusia tertanamnya rasa keindahan dan keindahan itu adalah seni. Sebenarnya, kesedaran mengenai keindahan adalah satu faktor yang amat penting dalam Islam. Antara faktor yang penting dalam seni ialah hakikat, ketulenan/kesucian, kejujuran dan semua ini terjalin dalam jiwa orang-orang Islam. Seni menjadi bahan perantaraan yang menghubungkan satu jiwa pencipta dengan satu jiwa lain yaitu pengamat.

Kebudayaan Islam menganggap bahwa seni, sebagai nilai tempat bergantungnya seluruh validitas Islam. Karena nilai seni keindahan

${ }^{11}$ Sidi Ghazalba, Asas Kebudayaan islam: Pembahasan Ilmu dan Filsafat Tentang Ijtihad, Fiqh, Akhlak, Bidang-bidang Kebudayaan, Masyarakat dan Agama, (Jakarta, Bulan Bintang, 1978), h. 307. 
Alquran, merupakan Hujjah untuk kebenaran dari Illahi. ${ }^{12}$ Dalam konteks pemikiran dan kebudayaan, seni Islam telah diakui sebagai bagian dari aktifitas religius. ${ }^{13}$ Contoh saja, bacaan Shalawat Nabi, yang dilantunkan dengan berbagai macam lagu, begitu pula dengan senandung nasyid dimana hal tersebut sudah menjadi kebudayaan religius dalam masyarakat. Oleh karena itu seni dianggap sebagai salah satu pokok dari kebudayaan, yang merupakan salah satu aspek dari agama Islam.

\section{Nasyid Sebagai Kesenian Islami}

Pada awalnya sejarah nasyid pertama kali dibawakan dengan alunan bercorak padang pasir, tetapi kini kumpulan grup nasyid telah membawa perbagai bercorak baru untuk para pendengar. Pembaharuan ini menjadikan lagu-lagu nasyid lebih menarik dan bersifat lebih daya saing dalam bidang seni. Kata nasyid sendiri berasal dari bahasa Arab yang oleh Munawir. ${ }^{14}$ diartikan sebagai senandung atau nyanyian. Akar kata nasyid adalah nasyd, artinya hymne. Dengan demikian, asal makna nasyid adalah senandung pujian atau sanjungan, dalam hal ini sanjungan kepada Allah, Rasulullah saw dan para sahabatnya, serta keluhuran syariat Islam. ${ }^{15}$

Nasyid dipercaya sudah ada sejak zaman Nabi Muhammad. Syair thola'al badru 'alaina (yang artinya telah muncul rembulan di tengah kami) yang kini kerap dinyanyikan oleh tim qosidah dan majelis ta'lim, adalah syair yang dinyanyikan kaum muslimin saat menyambut 307.

${ }^{12}$ Buah Ismail al-Faruqi, Islam dan Kebudayaan, (Bandung, Mizan, 1984), h.

${ }^{13}$ Salad Hamdi, Agama Seni, (Yogyakarta, Adipura, 2000), h. 72

${ }^{14}$ Dharmo Budi Suseno, (2005)

${ }^{15}$ Romli, Asep Syamsul M, Kembalikan nasyid pada Khittahnya, (Bandung, Marja, 2006), h. 17 
kedatangan Rasulullah saw ketika pertama kali hijrah ke Madinah. Nasyid kemudian berkembang seiring dengan situasi dan kondisi saat itu. Misalnya nasyid di Timur Tengah yang banyak mengumandangkan pesan jihad maupun perlawanan terhadap imperialisme Israel lebih banyak dipengaruhi oleh situasi politik yang ada saat itu.

Di tanah air, perjalanan Nasyid di awal sekitar era 80-an, ketika Mahasiswa-mahasiswa muslim menyanyikan syair berbahasa Arab sebagai wujud solidaritas saudara-saudara mereka di Palestina. Pada akhir tahun 90-an grup-group Nasyid di tanah air tumbuh bak cendawan di musim hujan. Hal ini paling tidak menandakan kerinduan masyarakat kita terhadap apa yang kerap disebut sebagai seni Islam. ${ }^{16}$

Nasyid merupakan senandung yang biasanya bercorak Islam dan mengandung kata-kata nasihat, kisah para nabi, memuji Allah, dan yang berkaitan dengan dengan Islam lainnya. Biasanya nasyid dinyanyikan secara acappela Atau dengan diiringi gendang (duff). Metode ini muncul karena banyak ulama Islam yang melarang penggunaan alat musik kecuali alat musik perkusi.

Seni Nasyid adalah seni musik Islami ( handasah al- shawat) yang mendendangkan syair-syair Qur'an dan irama-irama yang syahdu seni Nasyid yang berisikan ajaran-ajaran dan penuh ajaran Islam yang banyak mengandung muatan dakwah dan bimbingan melalui seni musik atau seni suara yang indah. Seni Nasyid dapat berbentuk doa-doa agama yang dinyanyikan dengan lagu paling enak dan suara paling lembut sehingga menggembirakan hati dan menggoyangkan perasaan. ${ }^{17}$

\footnotetext{
${ }^{16}$ Sri Yulianti, (2002), h. 40

${ }^{17}$ Yusuf Qaradhawi, 1998, h. 117
} 
Orang yang menyanyikan nasyid biasanya disebut munsyid, sedangkan arti munsyid itu sendiri adalah orang yang melantunkan atau membacakan syair. Nasyid tidak hanya sekedar lagu, akan tetapi memiliki nilai spiritual yang tinggi baik dari segi syairnya maupun munsyidnya. Syair atau lirik nasyid harus memiliki pesan ruhani atau pesan Islami yang kuat. Imam Al Mawardi mengatakan bahwa syair-syair yang diungkapkan oleh orang-orang Arab lebih disukai apabila syair itu mampu menumbuhkan rasa waspada terhadap tipuan atau rayuan dunia, cinta kepada akhirat, dan mendorong kepada akhlak yang mulia.

Munsyid yang menyanyikannya harus mencerminkan kepribadian Islami yang kuat. Citra Islami harus ada pada diri seorang munsyid. Bisa jadi karena niat munsyid dalam bernyanyi yang tidak benar akan mempengaruhi penyampaian nasyid meskipin lirik nasyid tersebut sudah kuat pesan ruhiahnya. Bagi munsyid, nasyid merupakan salah satu sarana dalam berdakwah. Oleh karena itu, seorang munsyid harus memahami falsafah berdakwah dalam nasyid, yaitu menyampaikan pesan dalam nasyid agar tersampaikan kepada pendengarnya. Seorang munsyid harus mampu membuat pendengarnya tergerak untuk mengingat Allah dan senantiasa berbuat kebaikan. Setiap syair yang dinyanyikan hanya akan sampai ke hati pendengar apabila dinyanyikan dengan hati, maka sudah merupakan kewajiban bagi seorang munsyid untuk mengaplikasikan nasyid yang disampaikannya dalam kehidupan sehari-hari.

Komunikasi Dakwah dalam Kesenian Nasyid

a. Makna-makna Verbal dalam Lagu-lagu Nasyid

Musik Nasyid mulai hadir di Indonesia sekitar tahun 1980-an. Saat itu nasyid hanya dilantunkan di forum-forum terbatas, oleh aktivis muslim di beberapa kampus dan sekolah. Oleh mereka, nasyid digunakan untuk 
mengobarkan semangat kelompoknya, dengan syair-syair yang bernuansa perjuangan fisabilillah (di jalan Allah swt.) yang menggelora. Lalu, memasuki era tahun 1990-an, nasyid mulai dikenal masyarakat luas dengan syair yang berisi nasihat, kisah-kisah para nabi, dan pujian kepada Allah swt. ${ }^{18}$ Pada Ramadhan tahun 2005, musik nasyid semakin akrab di telinga masyarakat Indonesia. Salah satu stasiun televisi swasta menyelenggarakan Festival Nasyid Indonesia dan Festival NTQ (Nasyid, Tausyiah, dan Qiroah).

Musik Nasyid adalah salah satu jenis musik atau senandung Islami yang berupa syair-syair pujian, perjuangan, dakwah, nasehat ataupun ingatan yang dibawakan dengan bersenandung. Nasyid adalah sarana dakwah dan media hiburan Islami yang tidak melalaikan diri kita dari Allah dan ajaran-Nya. Oleh karena itu, liriknya harus berisi ajakan kepada kebaikan dan kebenaran. ${ }^{19}$ Menurut Poetra, nasyid harus memiliki dua kriteria. Pertama, kekayaan nuansa seni dan kedua isi pesan syair yang menyerukan kebaikan dan demi kejayaan Islam. ${ }^{20}$ Hingga kini citra Nasyid di Indonesia senantiasa bernuansa kebenaran al-Islam.

Setiap pelaku komunikasi dengan demikian akan melakukan empat tindakan: membentuk, menyampaikan, menerima, dan mengolah pesan. Ke-empat tindakan tersebut lazimnya terjadi secara berurutan. Membentuk pesan artinya menciptakan sesuatu ide atau gagasan. Ini terjadi dalam benak kepala seseorang melalui proses kerja sistem syaraf. Pesan yang telah terbentuk ini kemudian disampaikan kepada orang lain.

\footnotetext{
${ }^{18}$ Adjie Esa Poetra, Revolusi Nasyid, (Bandung: MQS Publishing, 2004), h. 17

${ }^{19}$ Dharmo...., h. 86

${ }^{20}$ Ibid., h. 51
} 
Baik secara langsung ataupun tidak langsung. Bentuk dan mengirim pesan, seseorang akan menerima pesan yang disampaikan oleh orang lain.

Lagu-lagu religi, syair-syairnya berisikan ajaran-ajaran Islam yang banyak mengandung muatan dakwah dan bimbingan melalui seni suara yang indah. Muatannya juga dapat berbentuk do'a-doa' agama, pujipujian kepada Allah swt... Dengan demikian berdakwah melalui syairsyair lagu dapat menyentuh perasaan dan hati sanubari manusia khususnya umat Islam.

Lirik sebuah lagu merupakan kunci utama meski tidak dipungkiri sentuhan musik tidak kalah pentingnya untuk menghidupkan lagu tersebut secara keseluruhan. Untuk menyampaikan sebuah pesan tidak hanya tulisan yang dijadikan acuan sebagai tanda untuk berinteraksi dalam menyikapi pesan tersebut, tapi makna yang terkandung di dalam pesan tersebut yang menggugah. Dan bukan hanya instrument ataupun vokalika yang mendukung tapi faktor moment ketika pesan itu kapan harus disampaikan.

Karakteristik yang ada pada musik nasyid terletak pada syairnya yang berisi tentang ajakan pada kebaikan dan kebenaran syariat Islam. Nasyid yang kita kenal saat ini adalah sebuah jenis musik yang tidak terikat suasana hymne yang lazimnya selalu bertempo lambat (atau paling tidak sedang), bernuansa syahdu, khusyuk, khidmat, atau agung. ${ }^{21}$ Artinya nasyid bisa menyajikan lagu lambat, sedang, cepat hingga mars yang cepat. Namun, pada dasarnya nasyid tidak mementingkan instrumen musik, melainkan lebih mengandalkan lirik.

${ }^{21}$ Dharmo...., h. 16 
Nasyid salah satu cabang ilmu handasat al-Aswat (seni suara) dan seni dengar yang telah berkembang dengan pesatnya di Nusantara telah menjadi medium dakwah khususnya dalam penghasilan lirik lagu yang mengandungi nilai dalam mendidik masyarakat agar memperteguhkan keimanan dan ketakwaan kepada Allah, ketaatan kepada Rasulullah S.A.W, menginsafi kebesaran Allah, mengajak manusia menjadikan Sunnah sebagai panduan dan meletakkan kebenaran sebagai pedoman serta kebaikan dan keindahan wasilah dalam mencapai matlamat keredhaan Allah swt.

b. Lagu-lagu Nasyid sebagai Pesan dakwah

Nasyid merupakan nyayian yang biasanya bercorak keagamaan Islam dan mengandung kata-kata nasihat, kisah para nabi, memuji Allah dan yang seumpamanya. Nasyid ialah lagu yang biasanya dinyayikan secara kumpulan yang mengandungi seni kata yang berunsurkan Islam.

"Lagu yang baik untuk didengar adalah lagu yang berisi pesan yang mengandung arti yang bermakna bagi kehidupan kita. Banyak lagulagu yang sedang tenar di jaman sekarang ini tetapi tidak semua lagu memberikan pesan yang baik bagi si pendengarnya. ${ }^{22}$

Sebagai salah satu karya seni, musik relatif berpengaruh bagi setiap orang. Kekuatan dan keharmonisan dari lirik lagu dapat mempengaruhi pendengar secara emosional, karena biasanya musisi menyampaikan pesannya melalui lirik lagu. Banyak lagu-lagu yang sedang tenar di jaman sekarang ini tetapi tidak semua lagu memberikan pesan yang baik bagi si pendengarnya. Lagu yang baik untuk didengar adalah lagu yang berisi pesan yang mengandung arti yang bermakna bagi kehidupan kita. Untuk mengingat nasihat-nasihat agama yang bersumber

\footnotetext{
${ }^{22}$ Setiawan Permana, Strategi Komunikasi Dakwah Band Wali, dalam Lagu Cari Berkah, Jurnal Komunikasi Islam, Vol. 03 Nomor 01 Juni 2013.
} 
dari Alquran dan Hadist, baik yang dituturkan oleh wali, ulama, guru ngaji, atau orang tua, tentu bukanlah perkara mudah, karena banyak faktor yang mempengaruhi masuknya sebuah pesan ke telinga manusia. Dengan melalui lirik lagu, nasihat, himbauan dan anjuran agama akan lebih mudah diterima, karena lirik lagu menawarkan ritmis notasi dan kedalaman makna yang dapat membuat hati terbuai dalam alunannya.

Penyampaian dakwah tidak akan sampai kepada sasarannya apabila tidak membaur dan mengakomodasi dengan perilaku, kebudayaan, dan keadaan masyarakat. Lagu sangat digemari oleh masyarakat jadi berdakwah melalui lagu dirasa sangat tepat karena masyarakat tidak hanya menyalurkan hobinya saja untuk mendengarkan musik akan tetapi dengan lagu itu masyarakat juga biasanya memaknai setiap lagu yang dibawakan oleh musisi yang menciptakan lagu tersebut.

Fungsi lagu dalam masyarakat muslim yang telah teruji oleh sejarah di antaranya dapat menjadi salah satu media dakwah. Lagu religius atau lagu rohani disebut dengan berbagai sebutan, di antaranya adalah kasidah, barzanji, shalawat juga nasyid. Adapun menurut jenisnya, lagu-lagu Islami tidak dapat disebut sebagai lagu rohani yang murni karena tidak digunakan dalam proses peribadatan seperti halnya umat agama lain. Jadi lagu ini dikategorikan kedalam lagu rohani hiburan sekaligus sebagai media dakwah. ${ }^{23}$

Musik ${ }^{24}$ adalah bahasa universal. Melalui musik, siapapun dapat menyampaikan berbagai macam pesan seperti cinta dan persahabatan

${ }^{23}$ Ibid.

${ }^{24}$ Musik sebagai nyanyian, merupakan suatu media yang dijadikan sebagai alat penghibur oleh hampir setiap kalangan dizaman sekarang ini.Hampir tidak kita dapati satu ruangpun yang kosong dari musik dan nyanyian. Baik dirumah, di kantor, di warung, dan di toko-toko, dibus, angkutan atau mobil pribadi, di tempat-tempat umum, serta rumah 
(sosial), alam, kritik hingga berdakwah. Sebagai salah satu karya seni, musik relatif sangat berpengaruh bagi setiap orang. Dengan melalui lirik lagu, nasihat, himbauan dan anjuran agama akan lebih mudah diterima daripada nasihat, himbauan dan anjuran yang dilakukan oleh da'i, karena lirik lagu bisa membuat orang terbuai dalam aluanannya dan tanpa disadari pendengar setidaknya akan mengikuti apa yang terdapat dalam isi lagu tersebut. Lagu-lagu yang bernuansakan religi kian semakin dikenal dan digemari oleh masyarakat mulai dari anak-anak, remaja, dewasa sampai orang tua. Walaupun dikemas dengan nuansa modern dan universal, tetapi inti dari lagu yang disampaikan tetap tertuju pada syiar agama.

Pengembangan dakwah Islamiyah merupakan proses interaksi dari serangkaian kegiatan terencana yang mengarah kepada peningkatan kualitas keberagamaan Islam. Pengembangan merupakan alat untuk mencapai tujuan dakwah Islamiyah dalam proyeksi dan konstektualisasi ajaran Islam, proses transformasi ini merupakan kejelian dan kepekaan social bagi setiap da'i atau mubaligh agar mampu melakukan pendekatan kebutuhan yang dipandu oleh sumber Islam. Begitu pula dengan seni nasyid lirik atau syair disesuaikan dengan keadaan mad'u dan kepekaan sosial berdasarkan kondisi saat ini.

Dakwah bukan lagi menggunakan pendekatan yang hanya direncanakan secara sepihak oleh pelaku dakwah dan bukan pula hanya

sakit. Bahkan disebagian tempat yang dikenal sebagai sebaik-baik tempat di muka bumi,yaitu masjid juga tak luput dari pengaruh musik. musik adalah pengungkapan melalui gagasan melalui bunyi, yang unsur dasarnya berupa melodi, irama, dan harmoni dengan unsur pendukung berupa gagasan, sifat dan warna bunyi. Lihat, Suharto. M, Kamus Musik, (Jakarta: Gramedia, 1992), h, 86 
pendekatan tradisional mengutamakan besarnya masa tetapi memerlukan pendekatan partisipatif disamping pendekatan kebutuhan. ${ }^{25}$

Penyampaian dakwah tidak akan sampai kepada sasarannya apabila tidak membaur dan mengakomodasi dengan perilaku, kebudayaan, dan keadaan masyarakat, apa yang selalu mereka kerjakan dan mereka sukai, di sanalah kita bisa menjadikannya media untuk berdakwah. Hal semacam ini bisa dilakukan di antaranya melalui pop religi dan nasyid. Keuntungannya, pesan-pesan Islam akan sampai kepada mereka, tanpa mengganggu kegemaran mereka sekaligus mengalihkan dari hal-hal buruk ke hal yang positif, yakni dari lagu-lagu yang berbau kekerasan, fantasi, dan bahkan seksualitas teralihkan ke lagulagu yang bernuansa religi.

Nasyid juga turut mengajak manusia untuk berzikir kepada Allah swt di mana unsur-unsur zikir dan doa turut menghiasi seni nasyid, disamping dijadikan sebagai kaedah yang boleh membantu memudahkan hafalan Asmaul Husna, nama-nama nabi, sifat-sifat Allah dan Rasul-Nya, dan nama-nama surah yang terdapat dalam Alquran. Seni ini juga telah dijadikan sebagai alat bantu dalam proses pengajaran dan pembelajaran.

Pesan-pesan dakwah banyak terdapat di dalam syair atau nyanyian religius yaitu nyanyian yang dihubungkan dengan nuansa keagamaan. Agama merupakan tujuan dan isi dari nyanyian tersebut. Oleh karena itu nyanyian religius ini syair-syairnya hanya menceritakan kebesaran Alquran, kecintaan kepada Allah, Rasulullah, orang-orang saleh dari hamba Allah, kehidupan akhirat dan kenikmatan syurga yang menceritakan makna ketuhanan dan keimanan yang dibawa oleh

25 Fitri Yanti, Pembangunan Masyarakat Melalui Dakwah bil Hal (Suatu Pendekatan Psikologi), Jurnal Bina al-Ummah Vol. II, no. 1 Juni 2007, h. 68 
Rasulullah. Dimasukkan pesan pesan alquran di dalamnya sehingga jadilah nasyid sebagai musikalisasi pesan pesan agama Islam. Kecendrungan masyarakat dunia saat ini menjadikan nasyid sebagai genre baru dalam music.Jika dulu terkesan nasyid diminati kalangan orang tua justru sekarang anak anak muda lebih gandrung dengan nasyid.

c. Nasyid sebagai Media dakwah

Nasyid merupakan cabang seni yang bersendikan Islam, kerana mengandung lirik yang mengungkapkan perasaan, ingatan, kisah para nabi, seruan dakwah Islamiah dan meniupkan semangat dalam proses pembangunan bangsa dan negara. Nasyid sebagai wadah seni yang mampu membawa misi dakwah Islamiah ke tengah masyarakat dalam memenuhi tuntutan fitrah yang ada dalam diri manusia.

Seni Islam adalah seni yang dapat mengungkapkan keindahan dan konsep tauhid sebagai esensi aqidah, tata nilai dan norma Islam,yaitu menyampaikan pesan Ke-esaan Tuhan. Seni Islam dilhami oleh spiritualitas Islam secara langsung, sedangkan wujudnya dibentuk karakteristik-karakteristik tertentu. Seuatu bentuk seni yang dilandasi oleh hikmah. ${ }^{26}$

Nasyid juga telah menjadi medium melestarikan dakwah secara berhikmah, ini selaras dengan maksud Firman Allah dalam Surah an-Nahl (16) ayat 125 :

${ }^{26}$ Hikmah bisanya diartikan sebagai 'kebijaksanaan' dalam kaitan ini hikmah berhubungan dengan kata haqq(hak)berarti penilaian yang benar atau hukm(hukum) yang sesuai dengan hakikat atau situasi yang sebenarnya. Lihat Ensiklopedia Islam, h. 113 
Fitri Yanti, Komunikasi Dakwah dalam Kesenian Nasyid

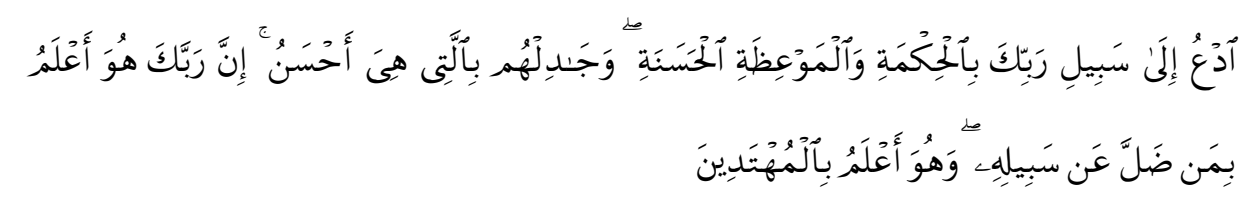

Terjemahnya:

"Serulah kepada jalan Tuhan-Mu dengan penuh hikmah dan pelajaran yang baik dan bantahlah dengan cara yang baik. Sesungguhnya Tuhanmu Dialah yang lebih mengetahui tentang siapa yang tersesat dari jalan-Nya dan dialah yang lebih mengetahui orang-orang yang mendapat petunjuk". ${ }^{27}$

Al-hikmah juga diartikan sebagai kemampuan da'i dalam memilih, memilah dan menyelaraskan teknik dakwah dengan kondisi objektif mad'u. Disamping itu juga al-hikmah diartikan sebagai kemampuan seorang da'i dalam menjelaskan doktrin-doktrin Islam, serta realitas yang ada dengan argumentasi logis dan bahasa yang komunikatif. Oleh karena itu al-hikmah adalah sebagai sebuah sistem yang menyatukan antara kemampuan teoritis dan praktis dalam dakwah.

Nasyid juga telah menjadi medium penyebaran dakwah dalam dunia penyiaran, di mana lagu nasyid telah menjadi salah satu bentuk seni hiburan yang disiarkan di kaca televisi dan radio, menjadi satu pendekatan kepada muda-mudi untuk memilih hiburan yang lebih baik dan bermanfaat.

Semarak Nasyid sebagai media dakwah dapat dilihat dari berbagai kegiatan yang banyak menggelar pertunjukan Nasyid. Hal ini menandakan bahwa Nasyid dapat diterima oleh masyarakat dan sebagai sarana media untuk menyampaikan pesan-pesan dakwah. Perjalanan seni nasyid Nusantara tidak terlepas dari tuntutan dan tanggungjawab 2010), h. 281

${ }^{27}$ Kementerian Agama RI, Alquran dan Terjemahnya, (Bandung: Fokusmedia, 
berdakwah pada jalan Allah adalah menjadi tanggungjawab ahli seni untuk terus mengajak manusia kepada kebaikan dengan tidak melupakan etika dan akhlak Islam yang perlu menjadi pakaian diri sepanjang masa agar nasyid mampu menjadi agen yang mengajak manusia kepada amar ma'ruf dan nahi mungkar. Nasyid itu metode dakwah yang menghibur. Melalui nasyid kita bisa menghibur sekaligus berdakwah, nasyid adalah satu seni yang dapat menghibur sekaligus memberikan pesan agama kepada pendengarnya.

Dengan demikian Nasyid adalah salah satu media yang efektif untuk berdakwah. Dengan Nasyid persoalan dakwah tidak di jelaskan secara gamblang, namun melalui nyanyian dan musik, sehingga orang yang baru pertama mengenal Islam bisa faham lewat Nasyid tersebut. Dengan menggunakan Nasyid sebagai media dakwah, maka dakwah yang disampaikan tidak akan menjemukan bagi mad'u. Karena dakwah dengan menggunakan media Nasyid, pertama mad'u akan tertarik dengan musik yang ditawarkan oleh munsyid ( pembawa Nasyid ) setelah mereka menyukai warna musiknya. Maka kemudian mereka memperhatikan isi Nasyid tersebut yang tiada lain adalah pesan-pesan dakwah yang mengajak manusia untuk selalu melaksanakan amar ma'ruf nahi mungkar.

\section{Penutup}

Pada masa sekarang ini masyarakat semakin menggemari dan menyukai lagu-lagu yang bernuansa religi dari anak-anak, remaja, orang dewasa hingga orang tua maka disitulah kesempatan kita untuk menyampaikan ajakan-ajakan yang mengajak mereka untuk melakukan hal-hal yang sesuai dengan syari'at Islam. Apalagi pada zaman sekarang 
ini banyak perilaku-perilaku masyarakat yang menjauh dari nilai-nilai ajaran agama Islam. Dalam hal ini diharapkan bisa mengaplikasikannya di kehidupan sehari-hari agar perilaku-perilaku yang tadinya jauh dari nilainilai ajaran Islam.

Nasyid yang merupakan salah satu cabang ilmu handasat al-Aswat (seni suara) dan seni dengar yang telah berkembang dengan pesatnya di Nusantara telah menjadi medium dakwah khususnya dalam penghasilan lirik lagu yang mengandung nilai dalam mendidik masyarakat agar memperteguhkan keimanan dan ketakwaan kepada Allah, ketaatan kepada Rasulullah saw, mengagungkan kebesaran Allah, mengajak manusia menjadikan Sunnah sebagai panduan dan meletakkan kebenaran sebagai pedoman serta kebaikan dan keindahan wasilah dalam mencapai matlamat keredhaan Allah swt. Nasyid juga telah menjadi medium penyebaran dakwah dalam dunia penyiaran, di mana lagu nasyid telah menjadi salah satu bentuk seni hiburan yang disiarkan di kaca televisi dan radio, bahkan menjadi hiburan masyarakat umum yang menjadi satu pendekatan kepada muda-mudi untuk memilih hiburan yang lebih baik dan bermanfaat.

\section{Daftar Pustaka}

Endang Saifuddin Anshari, Kuliah al-Islam, Jakarta: Rajawali, 1986.

Fitri Yanti, Pengembangan Masyarakat melalui Dakwah bil Hal (Suatu pendekatan Psikologi). Jurnal Bina al-ummah Vol. II, no, I, Juni 2007 , 2008. Tabsyir dan Tandzir dalam Dakwah perspektif Psikologi dalam Resolusi Konflik. Jurnal Al-ummah Vol III, no. I, Januari 2008

Gazalba,Sidi. Islam dan Kesenian; Relevansi Islam dengan Seni Budaya Karya Manusia, Jakarta: Bulan Bintang, 1988. 


\section{$\Delta$-nis 3 - 3 H, Volume 12 Nomor 2 Juli-Desember 2016: 211-231}

, Asas Kebudayaan Islam: Pembahasan Ilmu dan Filsafat tentang Ijtihad, Fiqh, Akhlak, Bidang-bidang Kebudayaan, Masyarakat dan Agama, Jakarta: Bulan Bintang, 1978.

Hamdy Salad, Agama Seni, Yogyakarta, Adipura, 2000

Hossain Nashr, Syeed. Spiritualitas dan Seni Islam, terj. Sutejo, Bandung: Mizan, 1994.

Ismail Buah Faruqi, Islam Dan Kebudayaan, Bandung: Mizan, 1984.

Mahfudh, sahal. Nuansa Fiqh Sosial, Yogyakarta: LKIS, 2003.

M. Soeharto, Kamus Musik, Jakarta: Gramedia, 1992.

Permana, Restiawan. Jurnal Komunikasi Islam "Strategi Komunikasi Dakwah Band Wali dalam Lagu Cari Berkah”. Volume 03, nomor 01 Juni 2013

Poetra, Adjie Esa. Revolusi Nasyid, Bandung. MQS Publishing, 2004.

Romli, Asep Syamsul M, Kembalikan Nasyid Pada Khittahnya, Bandung. Marja, 2006.

Suseno, Dharmo Budi, Lantunan Shalawat + Nasyid, Yogyakarta. Media Insani, 2005.

Sri Yulianti, Nasyid Menyeruk Pasar, Jakarta: Syiar, 2002.

Yusuf al- Qordhowi, Waktu dalam Kehidupan Muslim, Jakarta: Firdaus, 1998.

, Sistem Masyarakat Islam dalam Alquran dan Sunah, Penerjemah, Abdus Salam Masykur, Lc., Solo: Citra Islami Press, 1997.

, Fiqh Musik dan Lagu. Penerjemah Tim LESPISI, H. Achmad Fulex Bisyri, Lc. H. Awan Sumarno Lc., H. Anwar Musthofa, Bandung: Mujahid, 2002. 